\title{
HUBUNGAN PENGAWASAN DENGAN DISIPLIN KERJA PEGAWAI DINAS PARIWISATA DAN KEBUDAYAAN KOTA PADANG
}

\author{
Hikmah Putri Berliana ${ }^{1}$, Nellitawati $^{2}$, Rifma $^{3}$, Irsyad $^{4}$ \\ ${ }^{1}$ Administrasi Pendidikan, Universitas Negeri Padang $1,{ }^{2}$ Administrasi Pendidikan, Universitas Negeri Padang 2 , \\ ${ }^{3}$ Administrasi Pendidikan, Universitas Negeri Padang 3, ${ }^{4}$ Administrasi Pendidikan, Universitas Negeri Padang 4
}

Hikmah Putri Berliana1, e-mail: hikmahputrii12@gmail.com

Nellitawati², e-mail: nellitawati@fip.unp.ac.id

Rifma ${ }^{4}$, e-mail: rifmar34@fip.unp.ac.id

Irsyad $^{3}$, e-mail: irdyad111122@gmail.com

\begin{abstract}
This study aims to see how the discipline of work, the supervision of the leadership and the relationship of supervision with the work discipline in Department of the city of Padang. The population of research is all employees in Department of the city of Padang amounted to 54 people and the sample is 33 people that is determined based on techniques proportionate stratified random sampling. The instrument used is the questionnaire that contains about discipline and supervision. The result is a significant relationship between the supervisory with discipline of work employees in the Deparment of the city of Padang.
\end{abstract}

\begin{abstract}
Abstrak
Penelitian ini bertujuan melihat bagaimana disiplin kerja, pengawasan pimpinan dan hubungan pengawasan dengan disiplin kerja di Disparbud Kota Padang. Populasi dari penelitian in adalah semua pegawai di Disparbud Kota Padang yang berjumlah 54 orang dan sampelnya adalah 33 orang yang ditentukan berdasarkan teknik Propotionate Statified Random Sampling. Instrument yang digunakan adalah kusioner yang berisi tentang disiplin kerja dan pengawasan. Hasilnya adalah hubungan yang relevan antara pengawasan dengan disiplin kerja pegawai di Disparbud Kota Padang.
\end{abstract}

Kata Kunci: Disiplin Kerja; Pengawasan

How to Cite: Hikmah Putri Berliana, Nellitawati, Irsyad, Rifma. 2020. Hubungan Pengawasan dengan Disiplin Kerja Pegawai Disparbud Kota Padang. Journal Educational Administration and Leadership, Vol (N): pp. 34-37, DOI: doi.org/10.24036/jeal.v1i2

\section{Pendahuluan}

MSDM ialah salah satu ilmu yang merancang hubungan serta sebagai sumber daya yang dimiliki oleh seseorang untuk mencapai target organisasi. Dalam MSDM disiplin berperan penting, karena saat mengembangkan organisasi harus ada kedisiplinan pegawai dengan benar. Kedisiplinan merupakan fungsi kooperatif keenam MSDM sebab jika disipiln pegawai bagus, maka prestasi kerja yang akan didapatkan semakin tinggi, tidak adanya disiplin pegawai yang bagus, sulit untuk organisasi akan mendapatkan hasil yang baik(Hasibuan, 2011).

Disiplin kerja merupakan alat yang berperan bagi manajer saat berkoordinasi bersama bawahan supaya mereka bersedia merubah satu sikap dan satu cara dalam menambah kesadaran pegawai untuk menaati segala aturan organisasi. Disiplin kerja sangat penting, karena tanpa disiplin yang baik, tujuan dari organisasi tidak akan berhasil dengan maksimal (Nellitawati, 2012). Menurut Singodimedjo dalam (Edy, 2016) yang mempengaruhi disiplin kerja ialah kompensasi, pengawasan, aturan, kepemimpinan. Pegawasan yaitu sebagian 
dari peranan manajemen yang mempunyai tujuan agar segala rencana yang telah di tetapkan tercapai sesuai dengan tujuannya. Agar tujuan ini bisa tercapai diperlukan pengawasan yang dijalankan atasan kepada bawahannya, bila timbul kesalahan dapat segera dikoreksi secara dini dan bisa diteruskan dengan melaksanakan langkah koreksi. Maka demi mendukung terbentuknya disipilin kerja pegawai yang diinginkan, dapat disimpulkan bahwasanya pengawasan yang dijalankan atasan berdampak kepada disiplin kerja pegawai.

Akan tetapi menurut pemantauan penulis semasa PLMP di Dinas Pariwisata dan Kebudayaan Kota Padang, masih adanya kekurangan dalam disiplin kerja pegawai. Masalah tersebut bisa tampak berdasarkan fenomena berikut: (1) adanya beberapa pegawai yang masih menunda penyelesaian pekerjaan, (2) masih ada sebagian pegawai yang belum dapat memaksimalkan waktu dalam bekerja, (3) masih adanya sebagian pegawai yang kurag mampu menyelesaikan tugas dengan baik, (4) adanya beberapa pegawai yang tidak hadir atau datang terlambat untuk melaksanakan apel pagi. Fenomena tersebut menggambarkan bahwa disiplin kerja pegawai kurang dan belum optimal di Disparbud Kota Padang.

Disiplin kerja meliputi ketaatan, kepatuhan, kesadaran, tanggungjawab, dan juga hormat pada perjanjian yang telah dibuat antara organisasi dengan pegawai. Dengan kepatuhan pegawai terhadap kebijakan yang sudah ditentukan dan memiliki pegawai yang memiliki disiplin yang baik akan menciptakan iklim organisasi yang mendukung sehingga dapat berpengaruh positif pada kegiatan organisasi. Dalam melakukan aktivitas organisasi tanpa adanya pengawasan bisa menyebabkan disiplin kerja berkurang maka akan berdampak kepada aktivitas yang lain, maka bisa membatasi jalannya aktivitas dalam tercapainya target organisasi (Inayati, 2014). Aspek yang menyebabkan pelaksanaan pengawasan ialah kedisiplinan kerja pegawai (P. Siagian, 2010). Kedisiplinan yaitu keadaan yang menjadi patokan dalam mengetahui peran atasan pada kegiatan pengawasan dengan menyeluruh dapat dilaksanakan secara baik atau tidak dapat.

Pada penjelasan tersebut, bisa disimpulkan bahwasanya pengawasan atasan bisa mempengaruhi disiplin kerja karyawan. Oleh sebab itu pengawasan yang baik oleh atasan terhadap disiplin kerja maka karyawan dapat bersemangat dalam bekerja dengan giat, disiplin, dan bertanggung jawab sesuai aturan yang ditetapkan.

Akan tetapi, dilapangan pengawasan yang dilihat masih rendah, bisa dilihat pada beberapa fenomena yang berhubunan dengan pengawasan antara lain: 1) atasan masih belum optimal dalam memberikan perhatian kepada pegawai, 2) atasan kurang melakuakn tindakan perbaikan bagi pegawai yang melanggar aturan dan belum mendapat sanksi yang tegas untuk pegawai yang melanggar aturan.

Dari penjelasan tersebut, pengkajian ini bermaksud agar mengetahui Hubungan Pengawasan dengan Disiplin Kerja Pegawai di Disparbud Kota Padang.

\section{Metode Penelitian}

Bentuk pengkajian ini ialah pengkajian correlational yang mengaitkan variabel $\mathrm{X}$ yaitu pengawasan dan variabel Y yaitu disiplin kerja. Pengkajian ini untuk membuktikan kaitan pengawasan dengan disiplin kerja karyawan. Populasi penelitian ini ialah semua pegawai Disparbud Kota Padang, sebesar 54 pegawai. Sampel pengkajian ini didapatkan dengan memakai teknik stratified proportional random sampling dan didapat sampel sebesar 33 pegawai.

Bentuk data yang dipakai pada pengkajian ini yaitu data primer, merupakan data yang langsung diambil dari pegawai (Arikunto, 2010). Alat pengkajian ini ialah kusioner dengan model Skala Likert dengan 5 alternative tanggapan dan sudah di uji coba validitas dan reliabilitasnya. Teknik analisis data dilakukan berdasarkan verifikasi data, memberi skor masing-masing jawaban, tabulasi data, data yang sudah diberi skor dimasukkan kedalam distribusi frekuensi data, lalu mencari mean, median, modus dan standard deviation (SD), melakukan uji normalitas, menghitung koefisien korelasi dan menghitung keberartian koefisien korelasi.

\section{Hasil dan Pembahasan}

Sama dengan variabel penelitian, sehingga didapatkan data mengenai pengawasan dan disiplin kerja pegawai di Dinas Pariwisata dan Kebudayaan Kota Padang. Penjelasan tiap data tersebut dapat dirinci sebagai berikut:

\subsection{Hasil}

\section{Data Disiplin Kerja}

Pengambilan data disiplin kerja (variabel Y) diperoleh dengan menyebarkan kusioner sejumlah 33 pegawai. Nilai disiplin kerja yang didapatkan memencar dari niali terbawah 110 sampai dengan nilai tertinggi 145, nilai minimum ialah 33 dan nilai maximum ialah 155. Dari hasil olah data diperoleh nilai rata-rata $($ mean $)=129,4$, Median $=130$, Modus $=81,2$, dan Standard Deviation $(S D)=8,7$. 
Bisa ditinjau pegawai yang ada dalam rentang nilai rata-rata disiplin kerja ialah $18 \%$ dengan total frekunesi 6 pegawai. Dan yang berada di atas nilai rata-rata ialah 75\% dan berada dibawah nilai rata-rata adalah $6 \%$. Tingkatan disiplin kerja pegawai berada pada klasifikasi tinggi yaitu $86 \%$.

Data Pengawasan

Pengambilan data variabel pengawasan (variabel X) diperoleh dengan menyebarkan angket sejumlah 33 pegawai. Nilai pengawasan yang didapatkan memencar dari nilai terbawah 97 dan nilai tertinggi 133, nilai minimum ialah 30 dan nilai maximum ialah 150. Dari olah data, maka didapatkan nilai rata-rata $($ mean $)=$ 118,4, Median = 143,7, Modus = 194,3 dan Standard Deviation =9,3.

Bisa ditinjau pegawai yang ada dalam rentang nilai rata-rata ialah $6 \%$ dengan jumlah 2 pegawai. Dan nilai diatas rata-rata adalah $84 \%$ dan yang berada dibawah skor rata-rata adalah $9 \%$. Tingkat pencapaian pengawasan berada pada kategori cukup tinggi yaitu 78,2\%.

Tabel 1. Ulasan Mean Variabel Penelitian

\begin{tabular}{|c|c|c|c|c|c|c|c|c|c|}
\hline No & Variabel & Mean & Median & Modus & SD & $\begin{array}{c}\text { Nilai } \\
\text { Min }\end{array}$ & $\begin{array}{c}\text { Nilai } \\
\text { Maks }\end{array}$ & $\begin{array}{c}\text { Presentasi skor } \\
\text { maksimal ideal }\end{array}$ & Penafsiran \\
\hline 1. & Pengawasan & 118,4 & 143,7 & 194,3 & 9,3 & 97 & 133 & $78,2 \%$ & $\begin{array}{c}\text { Cukup } \\
\text { Tinggi }\end{array}$ \\
\hline 2. & $\begin{array}{l}\text { Disiplin } \\
\text { Kerja }\end{array}$ & 129,4 & 130 & 81,2 & 8,7 & 110 & 145 & $86 \%$ & Tinggi \\
\hline
\end{tabular}

\subsection{Hubungan Pengawasan dengan Disiplin Kerja Pegawai di Disparbud Kota Padang}

Bersumber pada ulasan data antara variabel pengawasan dengan disiplin kerja pegawai pada Disparbud Kota Padang $r_{\text {hitung }}=0,357>r_{\text {tabel }}=0,344$ pada tingkat kepercayaan $99 \%$ dengan $\mathrm{N}=33$. Dalam membuktikan signifikan kaitan dilakukan uji $t$ dengan data diperoleh $t_{\text {hitung }}=2,458>t_{\text {tabel }}=2,042$ pada tingkat kepercayaan 95\%. Kesimpulan analisis korelasi bisa nampak pada tabel dua berikut:

Tabel 2. Uji Coba Keberartian Coefficient Correlation Variabel X dan Variabel Y dengan tabel uji $r$ dengan tabel uji $t$

\begin{tabular}{|c|c|c|c|}
\hline \multirow{2}{*}{$\begin{array}{c}\text { Coefficient } \\
\text { Correlation } r\end{array}$} & Rtabel & \multirow{2}{*}{$\begin{array}{l}\text { Koefisien } \\
\text { Korelasi } t\end{array}$} & Rtabel \\
\hline & $\alpha=0,05$ & & $\alpha=\mathbf{0 , 0 5}$ \\
\hline 0,357 & 0,340 & 2,458 & 2,042 \\
\hline
\end{tabular}

Dari percobaan tersebut bisa disimpulkan adanya hubungan yang relevan antara pengawasan dengan disiplin kerja pegawai di Disparbud Kota Padang.

\subsection{Pembahasan}

Pengawasan

Berdasarkan hasil pengolahan data yang didapatkan diketahui bahwa pengawasan pada Disparbud Kota Padang berada pada kateogri cukup tinggi dengan capaian skor ideal $78,2 \%$. Hal ini berarti pengawasan pada Disparbud Kota Padang sudah cukup tinggi dan perlu ditingkatkan lagi agar mencapai pengawasan yang tinggi dan bahkan sangat tinggi..Pengawasan pada Disparbud Kota Padang perlu ditingkatkan terumata pada indikator tindak lanjut. Tindak lanjut ialah kegiatan yang bertujuan untuk mengkoreksi hasil kerja dan memperbaiki kekurangan yang ada.

Dari uraian diatas, disimpulkan bahwa tindak lanjut perlu dilakukan agar ada perbaikan untuk kedepannya. Tidak sekedar mengawasi dan mengkoreksi saja tetapi ada dan jelas apa perbaikan kedepan dari kegiatan mengawasi dan koreksi yang dilakukan oleh pimpinan.

\section{Disiplin Kerja}

Berdasarkan hasil pengolahan data yang didapatkan, diketahui disiplin kerja pegawai Disparbud Kota Padang berada di kategori tinggi dengan capaian nilai standar $86 \%$. Oleh sebab itu disiplin kerja pegawai 
di Disparbud Kota Padang sudah tinggi namun perlu ditingkatkan lagi agar mencapai disiplin kerja yang sangat tinggi sehingga hasil yang didapatkan menjadi tambah tinggi.

Hubungan Pengawasan dengan Disiplin Kerja Pegawai Disparbud Kota Padang

Hasil taksiran menyatakan bahwasanya antara pengawasan dengan disiplin kerja pegawai terdapat hubungan yang relevan yaitu $r_{\text {hitung }}=0,357>r_{\text {tabel }}=0,340$ di tingkat kepercayaan 99\%. Keberartian korelasi terdapat kaitan yang relevan yaitu $t_{\text {hitung }}=2,458>t_{\text {tabel }}=2,042$ di tingkat kepercayaan $95 \%$. Dengan begitu asumsi yang diuji bisa diterima. Pada asumsi ini ditemukan kaitan yang relevan antara pengawasan dan disiplin kerja pegawai.

Terdapatnya kaitan yang berarti pada pengawasan dan disiplin kerja membuktikan bahwasanya adanya aspek yang memengaruhi disiplin kerja yaitu pengawasan. Pengkajian tersebut menunjukkan adanya kaitan berarti pada pengawasan dan disiplin kerja. adanya pengawasan mengharuskan karyawan bisa bekerja disiplin. karyawan dapat bekerja dengan giat, konsisten serta spirit yang tinggi, sehingga hasil kerja akan maximum. Tetapi kebalikannya jika pengawasan rendah akan menyebabkan karyawan merasa kurang nyaman dalam bekerja sehingga hasil kerjanya kurang memadai.

\section{Kesimpulan}

Pada hasil pengkajian dan percobaan asumsi tentang hubungan pengawasan dengan disiplin kerja pegawai Disparbud Kota Padang, bisa disimpulkan bahwa disiplin kerja pegawai pada Disparbud Kota Padang telah berada dalam posisi tinggi. Dan pengawasan di Disparbud Kota Padang ada di posisi cukup tinggi. Adanya kaitan yang signifikan antara pengawasan dengan disiplin kerja.

Bersamaan ringkasan diatas, akibat adanya kaitan signifikan antara pengawasan dengan disiplin kerja, diharapkan atasan memperhatian peningkatan pengawasan untuk menaikkan disiplin kerja pegawai agar target organisasi tercapai dengan efektif. Untuk atasan Disparbud Kota Padang bisa menaikkan pengawasan karena sangat berdampak pada disiplin kerja. Dan diharapkan setiap pegawai Disparbud Kebudayaan Kota Padang agar menaikkan disiplin kerja.

\section{Daftar Rujukan}

Arikunto, S. (2010). Prosedur Penelitian Ilmiah. In Rineka cipta, Jakarta.

Edy, S. (2016). Manajemen Sumber Daya Manusia. Jakarta: Kencana.

Hasibuan, M. S. P. (2011). Manajemen Sumber Daya Manusia. Edisi Revisi Jakarta: Bumi Aksara.

Inayati, A. (2014). Hubungan Pengawasan dengan Disiplin Kerja Pegawai pada Dinas Pendidikan Pemuda dan

Olahraga Kabupaten Dharmasraya. Bahana Manajemen Pendidikan, 2(1), 86-91.

Nellitawati. (2012). Kontribusi Pengawasan Kepala Sekolah Terhadap Disiplin Kerja Guru SMA Negeri Di

Kecamatan Koto Tangah Padang. Pedagogi Jurnal Ilmu Pendidikan, 12(2), 24-31.

P. Siagian, S. (2010). Manajemen Sumber Daya Manusia. In Jakarta: cetakan kedelapan belas BUMI RAKSA. 